$12-2018$

\title{
Book Review: All Necessary Measures: The United Nations and Humanitarian Intervention
}

Deborah Mayersen

University of Wollongong

Follow this and additional works at: https://digitalcommons.usf.edu/gsp

\section{Recommended Citation}

Mayersen, Deborah (2018) "Book Review: All Necessary Measures: The United Nations and Humanitarian Intervention," Genocide Studies and Prevention: An International Journal: Vol. 12: Iss. 3: 182-183.

DOI:

https://doi.org/10.5038/1911-9933.12.3.1593

Available at: https://digitalcommons.usf.edu/gsp/vol12/iss3/17

This Book Review is brought to you for free and open access by the Open Access Journals at Digital Commons @ University of South Florida. It has been accepted for inclusion in Genocide Studies and Prevention: An International Journal by an authorized editor of Digital Commons @ University of South Florida. For more information, please contact digitalcommons@usf.edu. 


\title{
Book Review: All Necessary Measures: \\ The United Nations and Humanitarian Intervention
}

\author{
Deborah Mayersen \\ University of Wollongong \\ Wollongong, New South Wales, Australia
}

\begin{abstract}
All Necessary Measures: The United Nations and Humanitarian Intervention
Carrie Booth Walling

Philadelphia: University of Pennsylvania Press

320 Pages; Price: \$26.50 Paperback
\end{abstract}

Reviewed by Deborah Mayersen

University of Wollongong

When I tell my undergraduate International Studies students that the United Nations Security Council (UNSC) did not deal with matters of human rights until 1991, they are invariably surprised. In the 1970s, when the Cambodian genocide took place, "references to human rights were inappropriate and illegitimate for Security Council deliberation," and the genocide was never discussed there. ${ }^{1}$ When Vietnam's military action brought the genocide to a halt in 1979, however, it was condemned at the Council as an unacceptable breach of United Nations (UN) rules and Cambodia's sovereignty. Today, of course, issues of human rights are an integral component of Security Council discussions and deliberations. But that it was not always so, and how it came to be, are adeptly elucidated in All Necessary Measures. In this volume, the author illustrates how both human rights and sovereignty norms have coevolved since the end of the Cold War, changing the meaning of state sovereignty and the nature of military force at the United Nations.

The central claim of the book is that discourse matters. The arguments made at the Security Council about the cause and character of conflict, and the source of sovereign authority, shape the likelihood that the UN will or will not intervene in defense of human rights. As Walling states: "Power at the start of the twenty-first century is no longer simply about whose military can win but also about whose story can win." ${ }^{2}$ Walling's extensive analysis of Security Council documents has enabled her to adroitly build her case. She identifies three ways in which conflict is conceptualised at the UN, before analysing how these frameworks impact on UN responses. The intentional causal story characterises a conflict as one-sided, with systematic repression and widespread human rights violations. The inadvertent causal story presents a conflict as one of two or more parties involved in a cycle of violence, in which deaths and human rights violations occur but are not the purpose of the violence. The complex causal story characterises a conflict as multifaceted, complicated and tragic, with diffuse responsibility for human rights violations. Security Council members may tell these stories "sincerely or strategically", and they may evolve over time, but the framework in which they present the conflict influences subsequent responses. ${ }^{3}$ As Walling remarks:

The predominant story shapes Security Council decision making, and each story type has a different propensity to trigger the use of military force. The discursive representation of a conflict as intentional creates opportunities for humanitarian intervention while its discursive representation as inadvertent or complex forecloses such opportunities. ${ }^{4}$

In the chapters of All Necessary Measures, Walling illustrates her argument with several case studies. Chapter 2 explores the emergence of human rights discourse in the Security Council through the case of Iraq, 1990-1992. This chapter provides a refreshing and informative examination of the conflict in Iraq in this period. It guides the reader through the changing norms in Security

\footnotetext{
${ }^{1}$ Carrie Booth Walling, All Necessary Measures: The United Nations and Humanitarian Intervention (Philadelphia: University of Pennsylvania Press, 2013), 3.

${ }^{2}$ Ibid., 5 .

${ }^{3}$ Ibid., 245.

${ }^{4}$ Ibid., 27-28.

Deborah Mayersen. "Book Review: All Necessary Measures: The United Nations and Humanitarian Intervention." Genocide Studies and Prevention 12, 3(2018): 182-183. @2018 Genocide Studies and Prevention.

https://doi.org/10.5038/1911-9933.12.3.1593
} 
Council behavior, while avoiding the mire of what has become a deeply politized conflict. Chapter 3 examines the state collapse in Somalia, and the emergence of Security Council humanitarian intervention. In this case, the UNSC authorised an armed intervention for a strictly humanitarian cause for the first time. Genocide studies scholars might be less familiar with a crisis such as that in Somalia, but the evolution of UNSC discourse around humanitarian intervention and human rights, and the impact of the Somali case on subsequent Security Council deliberations, make this compelling reading.

Chapters 4 and 5 cover more familiar ground, examining UNSC discourse concerning Bosnia and Herzegovina and Rwanda. I was shocked to learn that the first mention of the word 'genocide' in Security Council records was not until 16 May 1994. This highlights the strength of the norm of non-intervention in domestic affairs prevalent within the Security Council until the end of the Cold War, notwithstanding the Genocide Convention or the commitments to human rights in the UN Charter. In chapter 5, Walling meticulously examines the UNSC response to the genocide in Rwanda. She makes a convincing case as to the central role of discourse in framing how Security Council members conceptualised the violence, and how this in turn influenced the responses for which they advocated. The situation in Rwanda had come to the attention of the Security Council in the early 1990s as one of civil war and been articulated as an inadvertent causal story. When the violence became both civil war and genocide, the inadvertent story continued to dominate. Efforts by non-permanent members (consulting with international NGOs) to present an alternative intentional causal story were not effective until June 1994, by which stage widespread evidence of the genocide made the inadvertent story untenable. It was only then that the Security Council began to respond meaningfully. By that stage it was far too little and far too late.

Chapter 6 explores another example of UNSC inaction, that of Kosovo. The response to the genocide in Darfur, the focus of chapter 7, was hardly more successful. But the case studies end on a more positive note, with chapter 8 focusing on the intervention in Libya. This is a rare example in which the UNSC did respond in a timely and decisive manner, in line with the new norm of the responsibility to protect. The articulation of only a single causal story in the UNSC about Libya - "an intentional story in which Libyan authorities were perpetrators of widespread and systematic crimes against innocent civilians" - contributes to explaining this response. ${ }^{5}$ In this chapter Walling explores the continuing evolution of norms around human rights and sovereignty. UNSC Resolution 1973, as she explains, was historic as the first "explicit authorization to use military force against a UN member to stop a perpetrator government from committing human rights atrocities." ${ }^{\prime \prime}$ A short section towards the end of the chapter also examines why Libya provoked a humanitarian intervention but the subsequent crisis in Syria has not. Perhaps a new and updated edition might explore this more thoroughly in future. The volume overall presents a positive trajectory with respect to the UNSC's record on human rights, but Walling does not fail to recognise the inconsistent and exceptional nature of humanitarian intervention. One can only hope that progress continues.

All Necessary Measures is an outstanding book. Thoroughly and impeccably researched, it offers a compelling argument as to the power of discourse at the UNSC, and in international relations more broadly. It has much to offer students and scholars of the United Nations, human rights, and in the field of genocide and mass atrocities. Diplomats and public officials could also learn a great deal from this analysis.

\footnotetext{
${ }^{5}$ Ibid., 214.

${ }^{6}$ Ibid., 215.
} 